https://doi.org/10.52058/2695-1592-2022-1(8)-108-117

\title{
Mariia Medvedieva
}

Candidate of Pedagogical Sciences, Associate Professor, Head of the Department Informatics and Information and Communication Technologies

Pavlo Tychyna Uman State Pedagogical University,

Uman, Ukraine, https://orcid.org/0000-0001-9330-5185

\section{Tetiana Hodovaniuk}

Doctor of pedagogical sciences, Associate Professor, Professor of Higher Mathematics and Methods of Teaching Mathematics Department, Vice-Rector for Research Pavlo Tychyna Uman State Pedagogical University,

Uman, Ukraine, https://orcid.org/0000-0002-7087-7102

\section{Anastasiia Medvedieva}

Master's student of 1 year of study, Faculty of Physics, Mathematics and Informatics Pavlo Tychyna Uman State Pedagogical University,

Uman, Ukraine, https://orcid.org/0000-0002-7598-2438

\section{PROBLEMS OF FINANCIAL CONTENT AS A MEANS OF FORMING FINANCIAL LITERACY OF STUDENTS IN MATHEMATICS LESSONS IN PRIMARY SCHOOL}

Abstract. A modern successful person must be financially literate, in particular, be able to manage their own and family finances, navigate the financial services market and so on. This has a positive effect not only on the level of kindness of citizens, but also on the economy of the state as a whole. Implementation of the cross-cutting line "Financial Literacy" is designed to develop students' thrift, ability to rationally use funds, plan costs, stimulate leadership initiatives, the ability to operate successfully in a rapidly changing technological environment, to provide students with better understanding of practical financial issues.

The fundamental role in the formation of financial literacy of students is played by the school course of mathematics, in particular primary school. The main task of

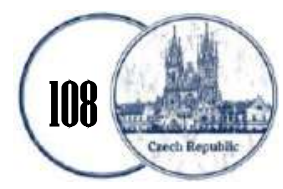


a mathematics teacher should be to intensify the learning activities of students, in particular through the introduction of mathematical problems of financial content in the educational process in mathematics. Mathematical problems of financial content perform: educational function, because their use is aimed at forming in students a system of knowledge, skills and abilities at different stages of learning; developmental function, because working with them develops the ability to comprehend the meaning of concepts, apply the acquired knowledge in practice, analyze the results, make appropriate generalizations, comparisons and conclusions; educational function, because economic and financial education in mathematics lessons can be carried out primarily through this class of tasks; controlling function as learning tasks.

Keywords: financial literacy, school mathematics course, cross-cutting key lines, mathematical problems of financial content.

Formulation of the problem. At the present stage of development of society one of the important and urgent problems facing the education system is the formation of a harmoniously developed personality of the student, able to quickly adapt to changing life situations, practically solve life problems, plan life strategy.

Thus, the Law "On Education" [5] states that "the purpose of complete general secondary education is the comprehensive development, education and socialization of the individual, capable of living in society and civilized interaction with nature, has a desire for self-improvement and lifelong learning, ready for conscious life choice and self-realization, responsibility, work and civic activity". This goal can be achieved by forming in students vital and key competencies necessary for every modern person for successful self-realization, self-determination, life.

An effective means of forming key competencies in students is to highlight in curricula such cross-cutting lines of key competencies as "Environmental Security and Sustainable Development", "Civic Responsibility", "Health and Safety", "Entrepreneurship and Financial Literacy".

One of the key competencies that has become widely relevant and will help solve the "crisis of financial literacy" of both adults and adolescents is "Initiative and Entrepreneurship".

Analysis of recent research and publications. The study of the problem of financial literacy is devoted to the work of foreign and domestic scholars T. Kizim, O. Kovtun, A. Lusardi, T. Lucy, O. Mitchell, S. Mundy, A. Nezlamov, D. Vasilieva, B. Prikhodko, N. Slavyanska, T. Smovzhenko, I. Sorkin, S. Yuri and others.

For example, Shawn Mundi, an international financial literacy consultant, sees financial literacy as the knowledge, understanding, skills, motivation and confidence a person needs to make the right financial decisions and act according to specific circumstances [3].

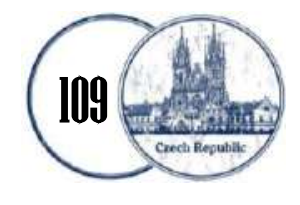


The purpose of the article: to demonstrate the possibility of forming financial literacy of students in mathematics lessons in primary school with the help of financial problems.

Presenting main material. Implementation of the cross-cutting key line "Entrepreneurship and financial literacy" in the educational process of secondary education is aimed at developing students' thrift, resource efficiency, cost planning, stimulating leadership initiatives, ability to operate successfully in a rapidly changing environment, providing students with better understanding of practical aspects of financial aspects. issues (savings, investing, borrowing, insurance, lending, etc.) [2]. This cross-cutting line is directly related to solving practical problems of business planning and real assessment of their own capabilities, drawing up a family budget, forming an economical attitude to natural resources, etc.

The fundamental role in the formation of financial literacy of students is played by the school course of mathematics, in particular primary school. Mathematics as a subject has sufficient potential for the formation and development of students' qualities that are necessary for a person to be successful in modern life.

This is confirmed by the results of one of the largest international PISA studies, which involves 15 -year-old students. This study examines the quality of education and covers more than 80 countries, which make up more than $80 \%$ of the world economy, determines the level of competencies, ie the ability of adolescents to use knowledge and skills acquired in school, with possible life difficulties and challenges. One of the three competencies assessed by PISA is mathematics: the ability to use mathematics knowledge and skills to overcome a variety of life challenges and problems related to mathematics. According to PISA, 36\% of Ukrainian students do not know how to perform basic calculations. The results of the study indicate that Ukrainian 15-year-old students have problems solving problems of grades 5-6 on the calculation of interest and actions with fractions.

PISA tasks are closely related to real life, including finance, but the current number of such tasks in math textbooks for grades 5-9 is insufficient. Therefore, the educational process in mathematics should be filled with problems of applied content, the solution of which students will contribute to the formation of financial literacy. After all, according to the Order of the Ministry of Education and Science №1336 of 09.12.2021 "On preparation and conduct of the main stage of the international study of the quality of education PISA-2022" this year Ukrainian students will again participate in the international study.

D. Vasilieva [4] in order to form students' financial awareness and development of financial literacy in the process of learning mathematics proposes to consider the following content lines: value of goods and services, family budget, insurance, banking, securities, charity, taxes, etc.

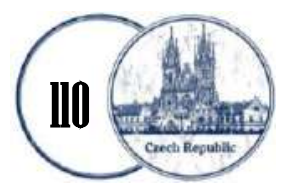


The main task of a mathematics teacher should be to intensify the learning activities of students, in particular through the introduction of mathematical problems of financial content in the educational process in mathematics. Mathematical problems of financial content perform: educational function, because their use is aimed at forming in students a system of knowledge, skills and abilities at different stages of learning; developmental function, because working with them develops the ability to comprehend the meaning of concepts, apply the acquired knowledge in practice, analyze the results, make appropriate generalizations, comparisons and conclusions; educational function, because economic and financial education in mathematics lessons can be carried out primarily through this class of tasks; controlling function as learning tasks.

It is necessary to begin to form financial literacy of pupils in mathematics lessons at the 5th grade in the primary school. In particular, for example, when studying the topic "Natural numbers and actions with them" it is necessary to offer to solve plot problems that contain real data on the calculation of the family budget, the possibility of registration of goods on credit, and so on. In the 6th grade when studying, for example, the topics "Attitudes and proportions. Interest calculations "," Rational numbers and actions with them "students should be asked to solve such problem tasks that will help develop the ability to manage their own and family funds, make decisions in financial transactions, assess credit risks, calculate expected and actual costs and more. In the 7th grade, when studying the topics "Functions", "Linear equations and their systems" it is necessary to offer to solve plot problems, which are related to the ability to manage their own and family finances, with historical examples of financial problems, etc. In the 8th grade when studying the topics "Rational expressions", "Square roots". Real numbers "," Quadratic equations "students should be asked to solve such plot problems that will help develop the ability to calculate taxes, payments, value of goods, explore and use the relationships of economic phenomena. In the 9th grade, when studying the topics "Inequalities", "Quadratic function", "Numerical sequences", "Fundamentals of combinatorics, probability theory and statistics" should offer tasks for calculating and analyzing the financial capacity of the family, taxes paid, personal decisions. and collective financial issues, etc. The use of applied tasks of financial orientation contributes to a better understanding of the material and forms the ability to use the acquired knowledge in specific situations [1].

In order to form in students in the process of learning mathematics mathematical competence and financial literacy, we propose to consider with students problems related to:

- value of goods and services:

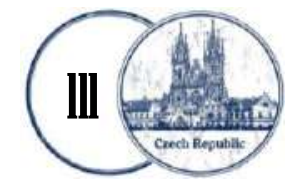


Exercise 1. In summer, a kilo of strawberries costs 60 hryvnias. Mariyka bought $1 \mathrm{~kg}$ of $200 \mathrm{~g}$ of strawberries. How many hryvnias will she receive from the remaining 200 hryvnias??

Exercise 2. Chocolate costs 32 hryvnias. On Sunday, the supermarket has a special offer: buying 2 chocolates, the third buyer receives a gift for 1 kopeck. How many chocolates can be bought for 200 hryvnias on Sunday?

Exercise 3. Petryk decided to give Iryna a bouquet of tulips, which cost 27 hryvnias apiece. Petryk has 500 hryvnias. What is the maximum number of tulips Petrik will have enough money, given that the bouquet should be an odd number of flowers?

Exercise 4. A train ticket for an adult costs 530 hryvnias. The cost of a student ticket is $60 \%$ of the cost of an adult ticket. How much is a student ticket?

Exercise 5. For $80 \%$ of the population of Ukraine, the electricity tariff from October 1, 2021 will be UAH 1.44 per $\mathrm{kWh}$, subject to consumption of up to 250 $\mathrm{kWh}$ per month. For all those who consume more than $250 \mathrm{kWh}$ per month, the price will remain the same - UAH 1.68 for the entire consumption. Until January 1, 2021, the following tariff was in force: electricity consumption up to $100 \mathrm{~kW} * \mathrm{~h} /$ month - UAH 0.9 per $1 \mathrm{~kW}$, over $100 \mathrm{~kW} * \mathrm{~h} /$ month - UAH 1.68 per $1 \mathrm{~kW}$. Figure 1 shows an electric meter with readings as of December 1, 2021. The previous figure as of November 1, 2021 was $10,716 \mathrm{~kW}$. Calculate: a) how many $\mathrm{kW}$ the family consumed in November; b) how much should be paid as of December 1, 2021? c) how much would have to be paid as of December 1, 2020?

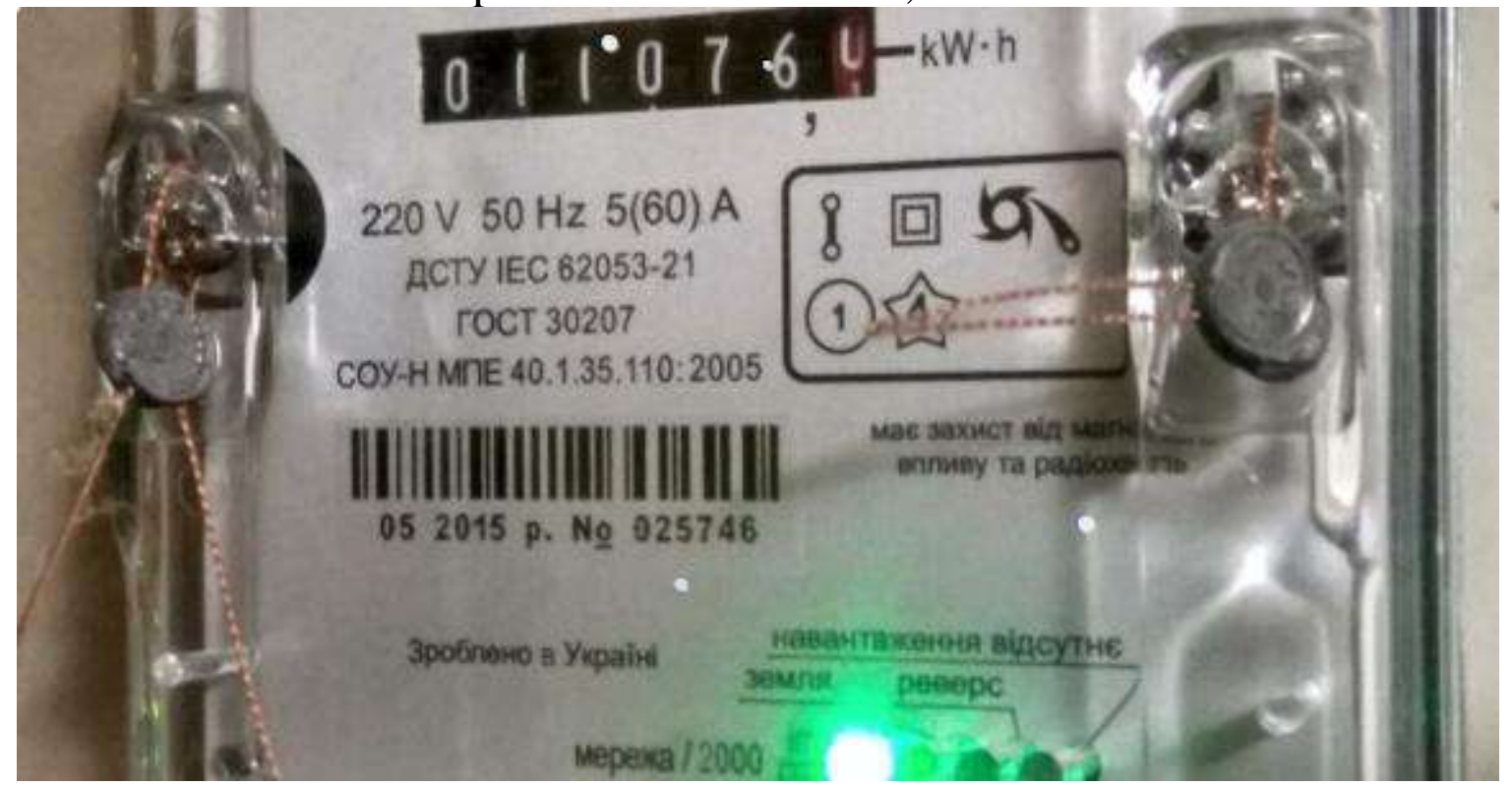

Fig. 1. Electric meter readings

Exercise 6. The monthly salary of a waiter is calculated on the principle: a fixed rate of 3800 hryvnias plus 3\% of the institution's income per month. Determine

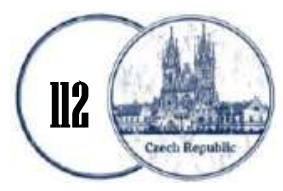


the function of the waiter's salary. Calculate the salary that the waiter received in the summer, if the monthly income of the institution is shown in the table.

\begin{tabular}{|c|c|c|c|}
\hline & June & July & $\begin{array}{c}\text { Augus } \\
\mathrm{t}\end{array}$ \\
\hline $\begin{array}{c}\text { Institutional income, } \\
\text { UAH / month }\end{array}$ & 68036 & 75200 & 73250 \\
\hline Salary, UAH & & & \\
\hline - family budget:
\end{tabular}

Exercise 1. Mom gives Sasha 200 hryvnias a week for out-of-pocket expenses and travel. Sasha spends $25 \%$ of the money received from his mother on the trip. From next month, the fare in transport will increase by $20 \%$. How much should mom give Sasha to keep his out-of-pocket expenses the same as before the rise in transport prices?

Exercise 2. The family's income is 29,000 hryvnias per month. Family expenses from September to December were by month: 22,000; 22,780 Hours; 24 $220 ; 25,800$ hryvnias. Determine the total amount of family savings for these months. What would be the total savings of the family for four months if its average monthly expenses were equal to: a) the minimum value for September-December; b) the maximum value for this period?

Exercise 3. Natalochka decided to go on vacation to the Black Sea in August. The cost of the ticket is 2800 hryvnias. The girl has only 3 months left to accumulate the required amount for rest. She decided to save money every week and started with 50 hryvnias, increasing this amount by 25 hryvnias every week. Will Natalochka have time to save the necessary amount to go on a trip to the sea?

Exercise 4. The income of a family consisting of a father, mother and daughter-student is 10,773 hryvnias per month. The numbers to which the income of each family member is proportional form a geometric progression, the third member of which is 12. If you put 9 instead of 12, the numbers form an arithmetic progression. How much money does each family member earn?

- insurance:

Exercise 1. The Doroshenko family consists of three people: a father, a mother and a schoolboy. Last year, the father was ill twice, the mother three times, and the child nine times. Each time they sought help in a private clinic, where they had to visit a doctor three times and take tests twice. The first visit to the doctor costs 660 hryvnias, the second appeal -510 hryvnias, tests -300 hryvnias.

If you take out a health insurance policy, you do not need to pay for each service. The cost of policies is:

- for an adult: 16,200 hryvnias;

- for a child - 19,200 hryvnias.

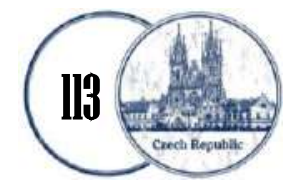


a) which of the family members would be cheaper to issue a policy than to pay for each service?

b) by how much?

Exercise 2. Ivan's car was insured with CASCO for 330,000 hryvnias. After the accident, which was caused by Ivan, an expert of the insurance company estimated the amount of damage at 34,200 hryvnias. Under the terms of the contract, the amount of liability that is not covered by the insurance company (unconditional deductible) is 18,000 hryvnias. How much should the insurance company pay Ivan?

\section{- banking:}

Exercise 1. Matthew has long dreamed of having a professional SLR camera. The model he likes costs 23,700 hryvnias the most. Matthew expects to receive a prize of 24,000 hryvnias in the near future, but he does not want to wait. Matthew decided to pay for the camera with a credit card. If he repays the debt during the grace period, he will not have to pay interest. However, if he pays the funds later, the bank will charge interest at the rate of $22 \%$ per annum for the entire period of the loan (from the date of payment in the store to the date of repayment). Matthew made the purchase 20 days before the end of the grace period, and received the award late, 15 days after the end of the grace period on the card. What amount of interest will Matthew have to pay? Will he have enough bonuses to pay off the loan in full (repay the debt and pay interest)?

Exercise 2. On January 1, Oleg placed UAH 300,000 on a bank deposit at $12.5 \%$ per annum. The term of the deposit is one year. Interest is paid at the end of the term together with the return of the deposit. A year later, Oleg wants to buy a car worth 414,000 hryvnias, receiving a deposit with interest and adding the amount of which is not enough to buy. How much should Oleg pay to buy a car after returning the deposit?

Exercise 3. 100 Japanese yen costs 24.48 hryvnias. How much can you buy for 100 hryvnias? Round the answer to the nearest whole number.

Exercise 4. The bank charged the depositor 60 hryvnias of interest money. Adding 440 hryvnias to the total amount, the depositor left his savings in the bank for another year. At the end of the year, interest was accrued again. And now the contribution together with interest is 2575 hryvnias. What amount was put on deposit in the beginning?

Exercise 5. What capital should be put in the bank at 20\% per annum in order to receive UAH 10,000 together with interest in 3 years? Round the answer to thousands.

Exercise 6. Bank A performs the following operations: 1) issuance of loans; 2) acceptance of cash on deposits; 3) providing advice to clients; 4) foreign exchange transactions; 5) receiving payments from the population; 6) sale of securities. Bank B carries out the following operations: a) receiving payments from

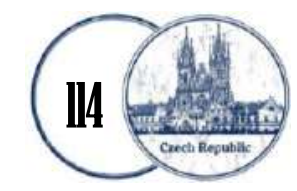


individuals; b) foreign exchange transactions; c) providing advice to clients; d) sale of commemorative coins; e) acceptance of worn banknotes. Find out what operations the bank will carry out in the case:

a) $A \cup B$; b) $A \cap B$; c) $A \backslash B$; d) $B \backslash A$.

- securities:

Exercise 1. To increase his savings, Petro Oleksiyovych bought 100 shares of Ukrnafta's Ukrainian company for 140 hryvnias apiece, 50 shares of an American processing company for $\$ 45$ apiece, and 10 shares of an American IT company for $\$ 95$ apiece. On the day of purchase, the exchange rate against the hryvnia was 28,043 hryvnias per dollar. Shares of Ukrnafta PJSC rose by $10 \%$ over the year, processing - fell by $7 \%$, IT - rose by $35 \%$. The dollar exchange rate decreased to UAH 27.96 per dollar a year later. What is the percentage change in the amount of Petro Oleksiyovych's savings in hryvnias for the year? What percentage has changed the amount of savings of Peter Alekseevich in dollars for the year?

Exercise 2. Tatiana's grandfather owns 30 shares of Ukrnafta PJSC, for which he received a profit of UAH 7,740. What profit can Tatiana's grandfather get if he owns 45 shares in the same company?

- taxes:

Exercise 1. As of 2021, the amount of tax revenues to the budget of Ukraine amounted to 1485301.4 million hryvnias. Write in standard form the components of the total revenue shown in the table.

\begin{tabular}{|c|c|c|}
\hline № & Tax & $\begin{array}{c}\text { Amount, UAH } \\
\text { million }\end{array}$ \\
\hline 1 & Personal income taxes & 309073,8 \\
\hline 2 & $\begin{array}{c}\text { Excise tax on excisable goods } \\
\text { produced in Ukraine }\end{array}$ & 76430,9 \\
\hline 3 & Corporate income tax & 161722,3 \\
\hline 4 & $\begin{array}{c}\text { Rent and payment for the use of } \\
\text { other natural resources }\end{array}$ & 58069,0 \\
\hline 5 & Import duty & 33116,0 \\
\hline
\end{tabular}

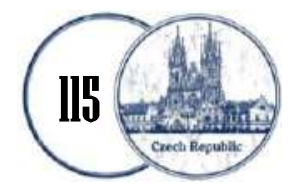



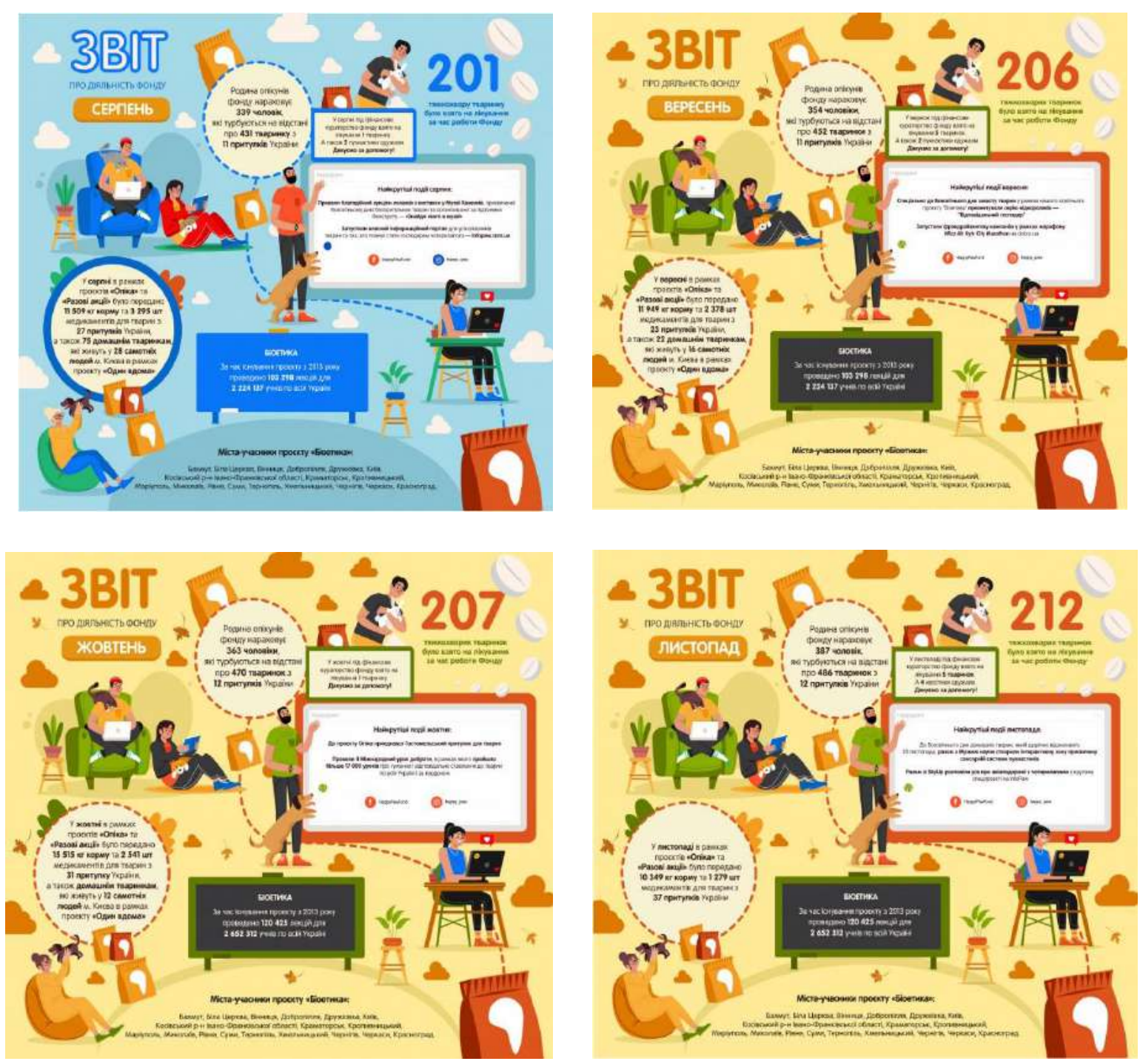

Exercise 2. Andriy and Serhiy received 5040 hryvnias for computer typing. During the work, they ordered pizza for lunch and ate it together, dividing it in half. In total, they paid 720 hryvnias for pizza, with $2 / 3$ of them being paid by Serhiy and the rest by Andriy. How should they share the income if the guys think that Andriy worked 2 times more than Serhiy?

- charity:

Exercise 1. According to the infographics of the Happy Paw Charitable Foundation (Fig. 2), which takes care of the fate of homeless cats and dogs for August - November 2021, we have data on: the number of kilograms of feed transferred under the projects "Guardianship" and "One-time shares", number of families - guardians of the fund, the number of animals taken for treatment under the financial supervision of the fund, etc.

Fig. 2. Infographics of the Happy Paw Charitable Foundation reporting for August-November 2021

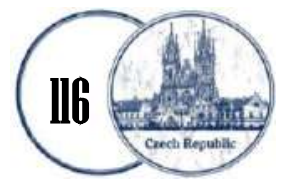


Analyze all the achievements of the Foundation during this period. Using MS Excel, build a chart "Dynamics of statistical indicators of achievements of the charity fund "Happy Paw".

Conclusions. Thus, the school course of mathematics plays an important role in shaping the financial literacy of students. Teaching mathematics should contribute to the formation of students' practical skills and abilities they need in everyday life: the ability to comprehend the meaning of concepts, analyze results, make appropriate generalizations, comparisons, conclusions and more. One of the effective means of forming financial literacy of students in the process of learning mathematics are problems of applied content.

Applied financial orientation of school mathematics course should demonstrate the connection between mathematics and financial transactions in everyday life, provide in-depth knowledge in the study of a particular topic and the application of knowledge in life, promote interest in learning and increase cognitive activity and independence of students.

\section{References:}

1. Matematyka. 5-9 klasy. Navchalna prohrama dlia zahalnoosvitnikh navchalnykh zakladiv [Maths. Grades 5-9. Curriculum for secondary schools]. (2017). mon.gov.ua. Retrieved from https://mon.gov.ua/ua/osvita/zagalna-serednya-osvita/navchalniprogrami/navchalni-programi-5-9-klas [in Ukrainian].

2. Metodychni rekomendatsii potentsiinym avtoram shchodo pidhotovky pidruchnykiv dlia 10 klasu zakladiv zahalnoi serednoi osvity [Methodical recommendations to potential authors on preparation of textbooks for 10th grade of general secondary education institutions]. (n.d.). ips.ligazakon.net. Retrieved from https://ips.ligazakon.net/document/view/MUS29290?an=9 [in Ukrainian].

3. Mundy, Sh. (2012). Rekomendatsii shchodo rozrobky natsionalnykh stratehii z finansovoi hramotnosti [Recommendations for developing national financial literacy strategies]. Mizhnarodnyi dosvid: stratehii i prohramy finansovoi hramotnosti - International experience: strategies and programs financial literacy. Retrieved from https://vaks.org.ua/images/news_ inform/UA_CPFL_Shaun_Mundy_FinLiteracy_Mar2012_ukr.pdf [in Ukrainian].

4. Vasylieva, D. (2017). Rozvytok finansovoi hramotnosti uchniv na urokakh matematyky [Development of students' financial literacy in mathematics lessons]. Matematyka v ridnii shkoliMathematics at home school. Retrieved from https://mathaxiology. files.wordpress.com/2017/11/ d0bcd0b0d182d0b5d0bcd0b0d182d0b8d0bad0b0-e284966_2017-c-2-7-1.pdf (дата звернення 29.12.2021) [in Ukrainian].

5. Zakon Ukrainy «Pro osvitu» [Law of Ukraine "On Education"]. (2017). (n.d.). zakon.rada.gov.ua. Retrieved from https://zakon.rada.gov.ua/laws/show/2145-19\#Text [in Ukrainian]. 